\title{
THERMAL STABILITY OF Pinus oocarpa AND MAIZE COB PARTICLEBOARDS
}

\author{
Estabilidade térmica de painéis aglomerados de Pinus oocarpa e sabugo de milho
}

\author{
Mário Vanoli Scatolino ${ }^{1}$, Thiago de Paula Protásion ${ }^{2}$, Rafael Farinassi Mendes ${ }^{3}$, Lourival Marin Mendes ${ }^{4}$
}

\begin{abstract}
Agricultural waste materials are generated in large quantities in Brazil. These can accumulate and cause serious environmental problems. One of the most commonly generated wastes in the brazilian agricultural culture is the maize cob. Being lignocellulosic in nature, the maize cob can find use as the raw material in the production of particleboards mainly concerned with furniture making. Therefore, studies regarding its thermal stability and fire resistance would be interesting. The aim of this study was to evaluate the combustibility and thermal stability of the particleboards produced from maize cob and Pinus oocarpa wood. The percentages in which maize cob was associated with Pinus oocarpa were $0 \%, 25 \%, 50 \%, 75 \%$ and $100 \%$. The panels were produced using $8 \%$ urea-formaldehyde and $1 \%$ paraffin. The pressing cycle parameters included: temperature $150{ }^{\circ} \mathrm{C}$, pressure of $3.92 \mathrm{MPa}$ during $10 \mathrm{~min}$. The combustibility curve analysis showed that the panels containing $25 \%$ content of maize cob had higher resistance to combustion. In general, the thermal stability decreased as the wood substitution by maize cob increased.
\end{abstract}

Index terms: Agricultural wastes; combustion; thermal properties.

\section{RESUMO}

Os resíduos agrícolas são materiais gerados em grande quantidade no Brasil, que podem se acumular, gerando problemas ambientais. Um dos resíduos mais gerados nas culturas agrícolas do Brasil é o sabugo de milho. Sendo um material lignocelulósico, o sabugo poderia ser utilizado como matéria-prima na produção de painéis aglomerados, cuja principal utilização é no setor moveleiro. Portanto, estudos sobre sua estabilidade térmica e resistência ao fogo seriam de interesse relevante. Objetivou-se, neste trabalho, avaliar a combustibilidade e estabilidade térmica de painéis aglomerados produzidos com sabugo de milho e madeira de Pinus oocarpa. As porcentagens de sabugo de milho utilizadas foram de $0 \%, 25 \%, 50 \%, 75 \%$ e $100 \%$ associadas com partículas de madeira de Pinus oocarpa. Os painéis foram produzidos com $8 \%$ de ureia-formaldeído e 1\% de parafina. Os parâmetros do ciclo de prensagem foram: temperatura de $150{ }^{\circ} \mathrm{C}$, pressão de 3,92 $\mathrm{MPa}$ e tempo de $10 \mathrm{~min}$. A análise das curvas de combustibilidade mostrou que os painéis, contendo $25 \%$ de sabugo, foram mais resistentes à combustão. Em geral, a estabilidade térmica decaiu à medida que foi aumentada a substituição de madeira por sabugo de milho.

Termos para indexação: Resíduos agrícolas; combustão; propriedades térmicas.

\section{INTRODUCTION}

Brazil produces a large quantity of lignocellulosic wastes that, in most cases, are not completely utilized, including corn cobs, coffee hulls, rice, pseudo stem of banana and sugarcane bagasse, etc (Mendes et al., 2010).

One such noteworthy agricultural waste is the maize cob, which is produced in large quantities in Brazil. According to CONAB (2013), the total area of corn cultivation in Brazil is approximately 15.84 million hectares; therefore, the production of a particleboards would be a useful alternative to reuse the generated waste. Scatolino et al., (2013) obtained good results with chipboard panels produced by a mixture of maize cobs and Pinus oocarpa in a 50:50 proportion.
As particleboard is widely used in the furniture sector, studies on its resistance to combustion and thermal stability characteristics would be opportune, particularly in order to assess the behavior of the panel, for example, in the event of a fire.

One way of evaluating the resistance to combustion is by subjecting the board to the combustibility test. Figueroa and Moraes (2009) define combustion and thermal treatment in the presence of oxygen or air in amounts sufficient to cause complete decomposition by an external heat source. However, literature regarding the resistance of the panels to combustion and their thermal stability is very limited.

The most widely used methods for the assessment of thermal stability are the Thermogravimetric analysis (TG) and Dielectric Thermal Analysis (DTA). Some

\footnotetext{
1Universidade Federal de Lavras/UFLA - Cx. P. 3037 - Cep: 37200-000 - Lavras - MG - Brasil - mario_paraiso@hotmail.com

${ }^{2}$ Universidade Federal de Goiás/UFG - Regional Jataí - Jataí - GO - Brasil

${ }^{3}$ Universidade Federal de Lavras/UFLA - Departamento de Engenharia/DEG - Lavras - MG - Brasil

${ }^{4}$ Universidade Federal de Lavras/UFLA - Departamento de Ciências Florestais/DCF - Lavras - MG - Brasil

Received in february 24, 2015 and approved april 27, 2015
}

Ciênc. Agrotec., Lavras, v. 39, n. 4, p. 348-354, jul./ago., 2015 
of the applications are mentioned by Silva, Paola and Matos (2007), including some researches on the thermal decomposition of organic, inorganic and polymeric substances and in studies on the evaporation and distillation of liquids and their reaction kinetics.

The aim of this study is to evaluate the resistance to combustion and thermal stability of particleboard made from maize cobs and Pinus oocarpa wood.

\section{MATERIAL AND METHODS}

\section{Collection and preparation of raw materials}

The maize cobs were obtained from the Department of Engineering at the Federal University of Lavras, Minas Gerais, while the 25 years old Pinus oocarpa trees were collected from the campus plantations of the same University.

The pine trees were chopped into small logs which were then heated in a tank filled with water at $60{ }^{\circ} \mathrm{C}$ for $24 \mathrm{~h}$. The logs were then processed in a roller to produce sheets $2 \mathrm{~mm}$ in thickness. These sheets were then crushed in a hammer mill and passed through a $6 \mathrm{~mm}$ aperture sieve. The maize cobs were processed in the same hammer mill, also with a $6 \mathrm{~mm}$ aperture sieve. The pine and maize cobs slivers were cleared using a vibrating sieve having a $2 \mathrm{~mm}$ mechanical opening for removing the fine particles. They were then dried at $70{ }^{\circ} \mathrm{C}$ until they achieved a moisture content of $3 \%$.

\section{Experimental design and production of the panels}

The experimental design consisted of five treatments that were evaluated with four percentages of wood waste substitution by maize cob (Table 1). For each treatment three panels were produced with nominal density of $0.70 \mathrm{~g} / \mathrm{cm}^{3}$.

Table 1: Experimental plan.

\begin{tabular}{ccc}
\hline Treatment & Pinus oocarpa $(\%)$ & Maize cob $(\%)$ \\
\hline 1 & 100 & - \\
2 & 75 & 25 \\
3 & 50 & 50 \\
4 & 25 & 75 \\
5 & - & 100 \\
\hline
\end{tabular}

For particleboards production, $8 \%$ ureaformaldehyde adhesive and $1 \%$ paraffin (based on particle dry weight) were used for all the treatments, which were then applied to the particles by spraying in a rotary drum. The particles already containing the adhesive and paraffin were next sent to a forming box where they were subjected to prepressing in a manual press at $0.29 \mathrm{MPa}$. The formed cushion was then subjected to hot pressing with a cycle of $160{ }^{\circ} \mathrm{C}$ pressing temperature and $3.92 \mathrm{MPa}$ pressure for a time of $8 \mathrm{~min}$.

\section{Samples preparation}

The samples were obtained with a buzz saw. For the test, quadrate samples $2 \times 2 \times 1.5 \mathrm{~cm}$ in dimension were used (length, width and thickness, respectively). The samples were conditioned for 10 days in a room at a temperature of $22 \pm 2{ }^{\circ} \mathrm{C}$ and relative humidity of $65 \pm 5 \%$.

\section{Combustibility test}

To evaluate panel behavior during combustion, the methodology adopted was the one described prior by Quirino and Brito (1991) and Paula et al., (2011). The method consisted of a device that included a galvanized iron plated burner, an aluminum base and wood, a temperature controller, a scale of $5 \mathrm{mg}$ precision, and an aluminum bulkhead involving the combustor to protect it from air interference during combustion.

Initially, the foundation and the combustor were placed on the precision balance. The combustor was charged with the samples. Ignition combustion occurred with $10 \mathrm{~g}$ of ethanol kept in a petri dish located on an aluminum base below the grid. The apparatus was then placed, and finally the temperature meter.

Every minute the mass of the panel and temperature of the system were recorded. The test was done in duplicate, and subsequently the mean curve for each treatment was obtained.

The time taken to reach the maximum temperature as well as the total weight loss for each of the treatments was recorded for further analysis. The maximum and minimum weight change for each treatment rate, observing the panel by the mass lost each interval time of $1 \mathrm{~min}$ were also calculated. Similar steps were followed for the temperature data.

\section{Thermogravimetric Analysis}

For the thermogravimetric analysis, the panels were reduced to powder, using the particle fraction size witch could pass through the 200 mesh sieve and get retained in the 270 mesh sieve. Composite samples of every replication were prepared corresponding to each treatment. The DTG-60H equipment (Shimadzu) was used for the analysis. Samples of around $4 \mathrm{mg}$ were subjected 
to a temperature gradient, ranging from room temperature to $600{ }^{\circ} \mathrm{C}$ at a heating rate of $10^{\circ} \mathrm{C} / \mathrm{min}$ using a nitrogen flow of $50 \mathrm{~mL} / \mathrm{min}$. By using the first derivative of the TG curve, to determine the weight loss versus temperature, the rate of loss of the mass per second and the characteristic peaks of thermal degradation of the panels were identified.

\section{RESULTS AND DISCUSSION}

\section{Combustibility test}

Figures 1 and 2 show variations in the mass of the panel and the system temperature for the combustibility test.

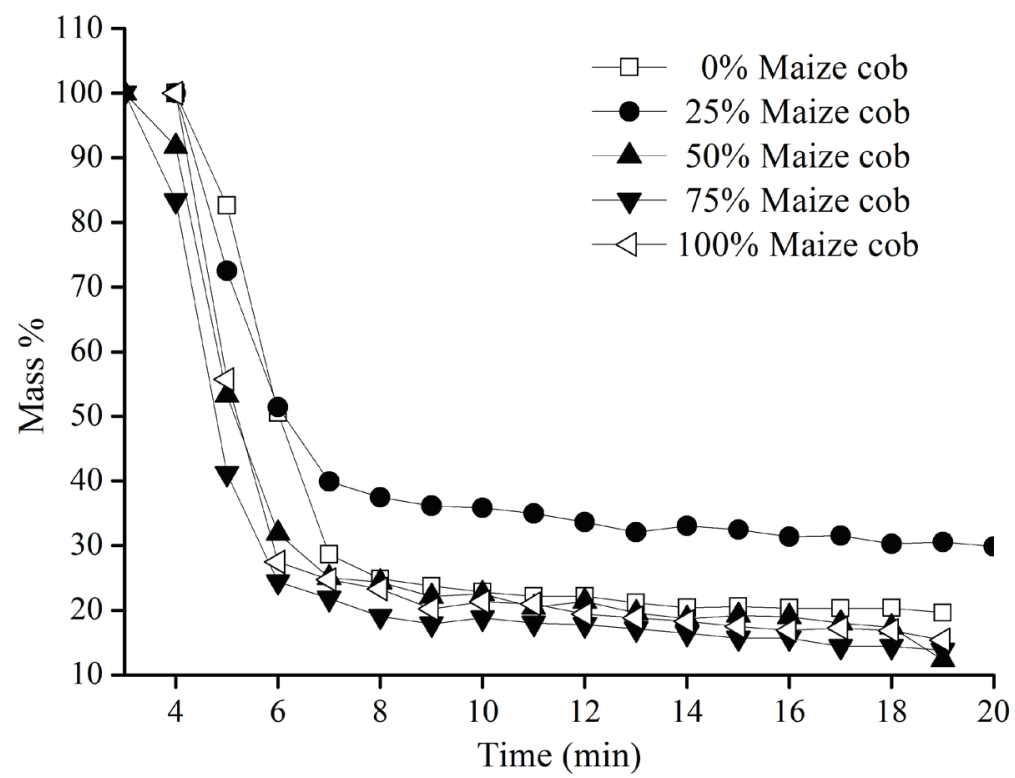

Figure 1: Mass variation during the combustion test.

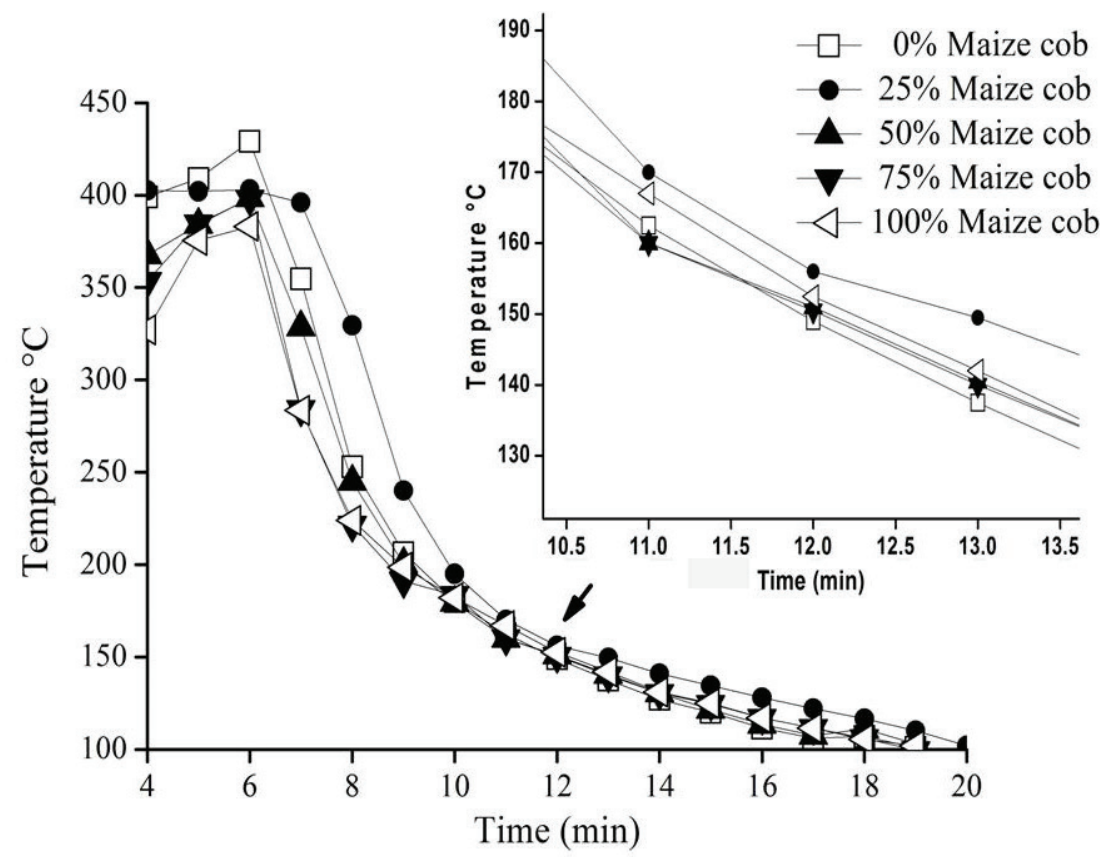

Figure 2: Temperature variation during the combustion test.

Ciênc. Agrotec., Lavras, v. 39, n. 4, p. 348-354, jul./ago., 2015 
Figure 1 reveals that the $25 \%$ maize cob panels were the most resistant to combustion, whereas, the panels made with 75 and $100 \%$ showed a total loss of mass of about $85 \%$ (Table 2). However the $75 \%$ maize cob panels showed a more pronounced loss of mass from the fourth minute of the test.

Table 2: Combustibility test parameters.

\begin{tabular}{cccc}
\hline $\begin{array}{c}\text { \% Maize } \\
\text { cob }\end{array}$ & $\begin{array}{c}\text { Maximum } \\
\text { Temperature }\left({ }^{\circ} \mathrm{C}\right)\end{array}$ & $\begin{array}{c}\mathrm{TTM}^{*} \\
(\mathrm{~min})\end{array}$ & $\begin{array}{c}\text { Total mass } \\
\text { loss }(\%)\end{array}$ \\
\hline 0 & 429 & 6 & 80.38 \\
25 & 403 & 6 & 70.14 \\
50 & 399 & 6 & 87.70 \\
75 & 398 & 6 & 86.20 \\
100 & 383 & 6 & 84.61 \\
\hline
\end{tabular}

*TTM - Time required to achieve the maximum temperature.

The higher compression ratio obtained for the panels made of $100 \%$ maize cob compared with those made using $75 \%$ and the greater holocellulose content of maize cob could be the answer to this fact. Scatolino et al., (2013) evaluated the chemical composition of maize cobs and found that it contained $76.6 \%$ holocellulose and $14.7 \%$ lignin, which may have contributed to the low resistance to combustion of the panels containing 50,75, and $100 \%$ of maize cob.

The panels produced with only pine wood showed similar features to those produced with $25 \%$ cobs until the sixth minute of combustion, after which the mass consumption of the panels made from $100 \%$ pine wood were more pronounced.

Figure 2 shows that the panels made only from the pine wood achieved the highest temperature peak, approaching to $450{ }^{\circ} \mathrm{C}$. This could have been due to the lower compression ratio of these panels, which led to a lower concentration of the particles in the panel. This lower concentration of particles to be consumed by the fire and, consequently, the higher content of voids enables a greater temperature rise compared with the maize cob panels.

The lignin content of pine wood $(28.3 \%)$ is considerably higher than in the maize cob $(14.7 \%)$ (Scatolino et al., 2013). Lignin is related to the higher calorific value of the wood and the highest enthalpy of combustion. Philipp and D'Almeida (1988) reported that some extractives contributed to the increased calorific value of the wood. In the case of pine, the resins present in wood may have influenced the achievement of the highest temperature peaks for the pine panels compared with those containing maize cob. The values of the extractives found for the wood in question was 5.2\% (Scatolino et al., 2013). In addition, the pine wood resin contains a component called turpentine. This is a flammable oleoresin obtained from the coniferous and which can find use as a chemical solvent, paint thinner in the industry and a starting material for the chemical synthesis of producing antiseptics, drugs, pesticides, insecticides and fuel additives (Kaplan et al., 2005).

Table 2 shows the maximum temperature values, as well as the time required to achieve them and the total weight loss for each treatment after the combustibility test.

The temperature peaks for all the treatments were achieved after 6 min of combustion. It was noticed that the temperature peaks decreased as the quantity of pine in the panels was reduced. This can be explained by the presence of turpentine in pine resin, which is a highly flammable liquid.

\section{Thermogravimetric analysis}

Figure 3 shows the weight loss in the panels as a function of temperature during the thermogravimetric analysis.

Similar behavior was observed in the panels in all the five treatments during TG, however, in the case of the panels containing $100 \%$ pine wood, it was observed that they had a higher thermal stability even at $320^{\circ} \mathrm{C}$. This fact could be explained by the higher lignin content in the pine wood in relation to the maize cob.

Apart from presenting high molecular weight, the lignin showed the highest thermal stability due to the presence of the carbon-carbon bonds between the monomer units of phenyl-propane and consequently, the stability of its aromatic matrix (Shafizadeh 1985; Bartkowiak; Zakrzewski, 2004; Sharma et al., 2004; Yang et al., 2006; Gani; Naruse, 2007; John; Thomas, 2008). The hemicelluloses are degraded at temperatures of between 180 and $350^{\circ} \mathrm{C}$ (Kim et al., 2006), cellulose between 305 and $375^{\circ} \mathrm{C}$ (Shafizadeh, 1985), and lignin between 250 and $500{ }^{\circ} \mathrm{C}$ (Shafizadeh, 1985; Kim et al., 2006). Thus, the thermal degradation process can be distinguished into two typical stages. Table 3 presents the decomposition stages of the panels during the TG analysis. 


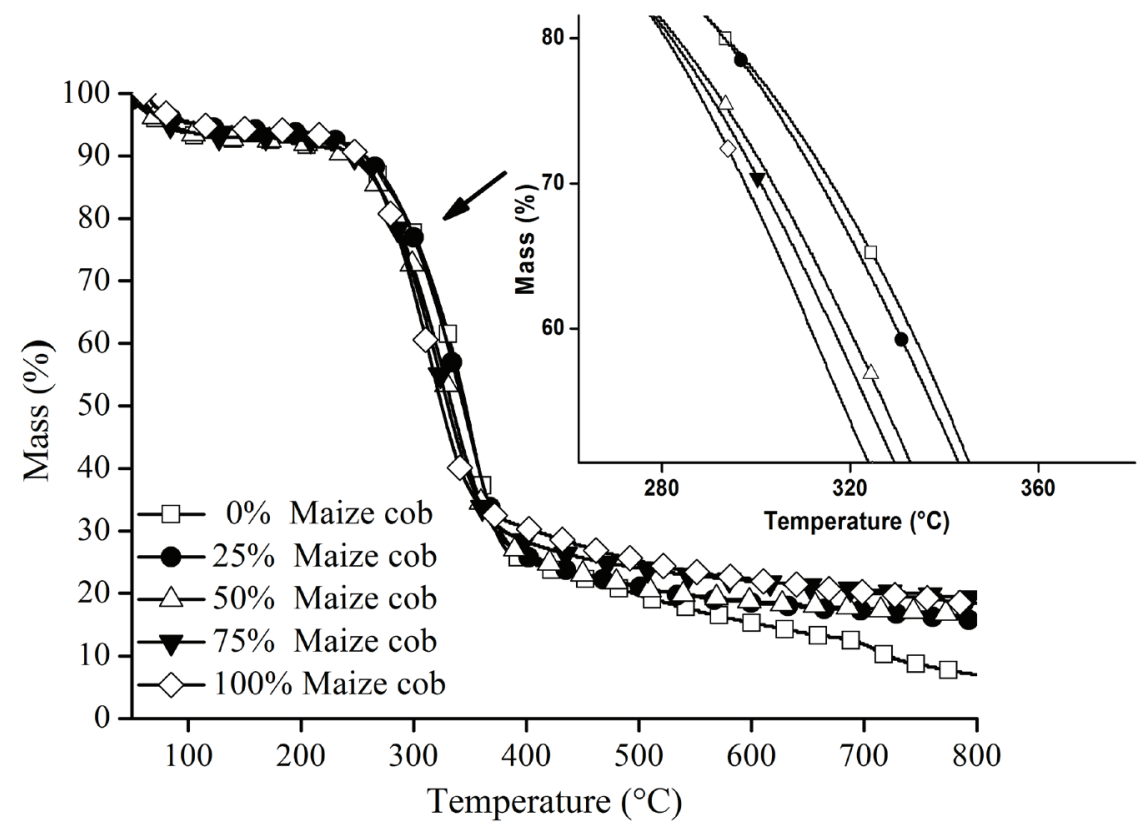

Figure 3: Weight loss in the panels as a function of temperature.

Table 3: Decomposition stages of the thermogravimetrics analysis.

\begin{tabular}{ccccccccccc}
\hline \multirow{2}{*}{ \% Maize cob } & \multicolumn{10}{c}{ Stage 1} \\
\cline { 2 - 11 } & T on & T end & T m & P\% & T on & T end & T m & P\% & T pico & PT\% \\
\hline 0 & 54.2 & 71.8 & 66.1 & 7.1 & 298 & 372 & 333 & 68.6 & 353 & 92.0 \\
25 & 53.9 & 102.1 & 70.1 & 5.3 & 317 & 377 & 330 & 72.0 & 348 & 83.6 \\
50 & 52.4 & 90.6 & 67.4 & 7.2 & 296 & 364 & 319 & 68.1 & 331 & 83.0 \\
75 & 56.9 & 82.3 & 71.2 & 6.8 & 278 & 360 & 315 & 67.6 & 324 & 80.0 \\
100 & 62.7 & 87.2 & 74.5 & 5.7 & 270 & 346 & 307 & 64.7 & 315 & 80.0 \\
\hline
\end{tabular}

$\mathrm{T}$ on: Onset temperature $\left({ }^{\circ} \mathrm{C}\right)$; T end: endset temperature $\left({ }^{\circ} \mathrm{C}\right)$; $\mathrm{T} \mathrm{m}$ : maximum degradation temperature $\left({ }^{\circ} \mathrm{C}\right)$; $\mathrm{P} \%$ : percent weight loss on stage; and the percentage of total mass loss (\% PT).

While analyzing Stage I regarding the water loss, it was observed that the samples showed similarity in the moisture content, and the panels containing 0 and $50 \%$ maize cobs had slightly higher values than the other treatments analyzed. The panels containing $25 \%$ maize cobs had a higher onset temperature $\left(317^{\circ} \mathrm{C}\right)$ when compared with the other panels. But at $377{ }^{\circ} \mathrm{C}$ (endset temperature) the hemicellulose had been degraded. In the case of those panels made from $100 \%$ pine wood, degradation started much earlier $\left(298^{\circ} \mathrm{C}\right)$, but the endset temperature of $372{ }^{\circ} \mathrm{C}$ was obtained as evident from the values obtained in Stage II (degradation occurs mainly by the hemicelluloses).
The largest amount of extractives in the maize cob or pine may have contributed to this fact. Scatolino et al., (2013) found values of $7 \%$ for extractives in maize cob. Protásio et al., (2012), developed briquettes made with processed waste from coffee beans. But the TG analysis of these briquettes revealed poor thermal stability. The authors also found high quantities of extractives in the coffee husk.

The presence of elevated levels of extractable matter (low molecular weight components) can promote biomass ignition at lower temperatures due to their higher volatility and thereby accelerate the thermal degradation process (Grønli, Varhegyi Di; Blasi, 2002; Shebani, Van 
Reenen; Meincken, 2008; Poletto et al., 2012). Similar to the combustion test, the maize cob panels revealed a decrease in the peak temperatures due to the increase in percentage of maize cob. In relation to the total mass loss, the pine panels were observed to be more resistant to thermal degradation when compared with the others.

\section{CONCLUSIONS}

On analysis of the curves generated by the combustibility test, the panels made with $25 \%$ maize cobs were found to be more resistant to combustion, which would experience less degradation in case of exposure to fire.

The chemical composition of the maize cob and Pinus oocarpa significantly influenced the thermal characteristics of the panels, particularly in the concentration of extractives and lignin.

The extractives present in pine wood resulted in the highest temperatures of the combustion peaks.

The TG analysis showed that, in general, the thermal stability of the panels decreased with the addition of the maize cobs.

\section{ACKNOWLEDGMENTS}

The authors would like to thanks the Minas Gerais Research Support Foundation (FAPEMIG) Brazilian National Council for Scientific and Technological Development (CNPq) for the financial support.

\section{REFERENCES}

BARTKOWIAK, M.; ZAKRZEWSKI, R. Thermal degradation of lignins isolated from wood. Journal of Thermal Analysis and Calorimetry. 77(1):295-304, 2004.

COMPANHIA NACIONAL DO ABASTECIMENTO. Acompanhamento da Safra Brasileira de Grãos 2012/13. Brasília, 2013. Available in: $<$ http://www.conab.gov.br/OlalaCMS/uploads/ arquivos/13_07_09_09_04_53_boletim_graos _ junho_2013.pdf $>$. Access in: Jun. 26, 2014.

FIGUEROA, M. J. M.; MORAES, P. D. DE. Comportamento da madeira a temperaturas elevadas. Ambiente Construído. 9(4):157-174, 2009.

GANI, A.; NARUSE, I. Effect of cellulose and lignin content on pyrolysis and combustion characteristics for several types of biomass. Renewable Energy. 32(4):649-661, 2007.
GRØNLI, M. G.; VÁRHEGYI, G.; DI BLASI, C.Thermogravimetric analysis and devolatilization kinetics of wood. Industrial Engineering Chemistry Research. 41(17):4201-4208, 2002.

JOHN, M. J.; THOMAS, S. Biofibres and biocomposites. Carbohydrate Polymers. 71(3):343364, 2008.

KAPLAN, C. et al. Engine performance and exhaust emission tests of sulfate turpentine and No: 2 diesel fuel blend. Petroleum Science and Technology. 23(11):1333-1339, 2005.

KIM, H.S. et al. Thermal properties of bio-flour-filled polyolefin composites with different compatibilizing agent type and content. Thermochimica Acta. 451(12):181-188, 2006.

MENDES, R.F. et al. Painéis aglomerados produzidos com bagaço de cana em associação com madeira de eucalipto. Scientia Forestalis. 38(86):285-295, 2010.

PAULA, L. E. R. et al. Produção e avaliação de briquetes de resíduos lignocelulósicos. Pesquisa Florestal Brasileira. 31(66):103-112, 2011.

PHILIPP, P.; D'ALMEIDA, M. L.O. Celulose e papel: tecnologia de fabricação da pasta celulósica. 2 . ed. São Paulo: IPT, 964p, 1988

POLETTO, M. et al. Thermal decomposition of wood: Influence of wood components and cellulose crystallite size. Bioresource Technology. 109:148-153, 2012.

PROTÁSIO, T. P. et al. Correlações canônicas entre as características químicas e energéticas de resíduos lignocelulósicos. Cerne. 18(3):433-439, 2012.

QUIRINO, W. F.; BRITO, J. O. Características e índices de combustão de briquetes de carvão vegetal. Brasília: IBAMA, LPF, 1991. 18 p. (Série Técnica, 13).

SCATOLINO, V. M. et al. Use of maize cob for production of particleboard. Ciência e Agrotecnologia. 37(4):330-337, 2013.

SHAFIZADEH, F. et al. Pyrolytic reactions and products of biomass. In: . Fundamentals of Biomass Thermochemical Conversion. London: Elsevier, 1985. Cap.6, p.183-217. 
SHARMA, R. K. et al. Characterization of chars from pyrolysis of lignin. Fuel. 83(11-12): 1469-82, 2004.

SHEBANI, A. N.; VAN REENEN, A. J.; MEINCKEN, $M$. The effect of wood extractives on the thermal stability of different wood species. Thermochimica Acta. 471(1-2): 43- 50, 2008.
SILVA, E.C.; PAOLA, M.V.R. V.; MATOS, J.R. Análise térmica aplicada à cosmetologia. Revista Brasileira de Ciências Farmacêuticas. 43(3):347- 356. 2007

YANG, H. et al. In-depth investigation of biomass pyrolysis based on three major components: hemicellulose, cellulose and lignin. Energy Fuels. 20(1):388-393, 2006. 